\title{
Pengaruh Pemahaman Investasi, Penggunaan Teknologi Media Sosial dan Hubungan Pertemanan Terhadap Minat Investasi Generasi Milenial di Pasar Modal
}

\author{
Putu Yolan Mahendrayani $^{1 *}$, Lucy Sri Musmini² iD \\ ${ }^{12}$ Jurusan Ekonomi Dan Akuntansi, Universitas Pendidikan Ganesha, Singaraja, Indonesia \\ *mahendrayaniy@gmail.com ${ }^{1 *}$
}

\begin{abstract}
Abstrak
Penelitian ini bertujuan untuk mengetahui pengaruh pemahaman investasi, penggunaan teknologi media sosial dan hubungan pertemenan terhadap minat investasi generasi milenial di pasar modal. Penelitan ini merupakan penelitian kuantitatif. Sampel yang digunakan adalah sebanyak 240 responden dengan teknik pengambilan sampel berupa purposive sampling. Dalam penelitian ini data yang digunakan adalah data primer yaitu kuesioner yang diukur menggunakan skala likert dan dianalisis menggunakan analisis linear berganda dengan program SPSS versi 23.0. Hasil penelitian menunjukan bahwa (1) pemahaman investasi berpengaruh negatif tidak signifikan terhadap minat investasi generasi milenial di pasar modal, (2) penggunaan teknologi media sosial berpengaruh positif signifikan terhadap minat investasi generasi milenial di pasar modal dan (3) hubungan pertemanan berpengaruh positif signifikan terhadap minat investasi generasi milenial di pasar modal.
\end{abstract}

Kata Kunci : Pemahaman Investasi, Penggunaan Teknologi Media Sosial, Hubungan Pertemanan, Minat Investasi

\section{Abstract}

This study aims to determine the effect of understanding investment, use of social media technology and friendship relationships on millennial generation's investment interest in the capital market. This research is a quantitative research. The sample used was 240 respondents with a sampling technique in the form of purposive sampling. In this study, the data used are primary data, namely questionnaires measured using a Likert scale and analyzed using multiple linear analysis with SPSS version 23.0 program. The results show that (1) understanding of investment has an insignificant negative effect on millennial generation's investment interest in the capital market, (2) the use of social media technology has a significant positive effect on millennial generation's investment interest in the capital market and (3) friendship has a significant positive effect on millennial generation's interest in investing in the capital market.

Keywords: : Understanding of investment, Use of Social Media, Friendship Relation, investment interest

\section{Pendahuluan}

Kegiatan investasi sangat penting dilakukan, karena dengan adanya kegiatan investasi suatu negara dapat memajukan negaranya, meningkatkan kesejahteraan masyarakatnya, mengurangi tingkat pengangguran serta meningkatkan pendapatan per kapita Rini, (2019).

PT Kustodian Sentral Efek Indonesia (KSEI) mencatat jumlah investor di pasar modal khususnya single investor identification (SID) mengalami perningkatan sejak tahun 2018 hingga tahun 2020. Tahun 2017 jumlah investor mencapai 1,12 juta SID, lalu pada tahun

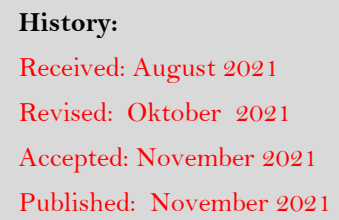


2018 meningkat menjadi 1,61 juta SID, tahun 2019 mencapai 2,48 juta SID dan tahun 2020 mencapai 3,61 juta (SID). Meningkatnya jumlah investor didominasi oleh kalangan anak muda atau generasi milenial. Walaupun setiap tahunnya terjadi peningkatan jumlah investor namun peningkatan tersebut masih terbilang sangat rendah jika dibandingkan dengan jumlah penduduk Indonesia yang mencapai 270 juta jiwa. Menyikapi hal tersebut Bursa Efek Indonesia telah melakukan serangkaian upaya untuk memperkenalkan pasar modal ke berbagai kalangan, salah satuya mahasiswa.

Mahasiswa merupakan salah satu calon investor muda yang paling menarik dan potensial untuk melakukan investasi, berbekal pembelajaran yang di dapat selama di bangku perkuliahan. Pengetahuan yang di miliki oleh mahasiswa tersebut dapat menjadi bekal untuk menghindari hal-hal yang tidak diinginkan dalam berinvestasi, Rusda (2020). Mahasiswa adalah generasi milenial yang diharapkan dapat menjadi agen perubahan (agent of change) masyarakat, dari masyarakat komsumtif menjadi masyarakat produktif dalam berinvestasi.

Kepala Kantor Bursa Efek Indonesia (BEI) Bali Andiyasa (2020) menyatakan bahwa Bali merupakan salah satu Provinsi yang mengalami peningkatan investor selama pandemi Covid-19. Namun pertumbuhan investasi di Provinsi Bali belum signifikan jika dibandingkan dengan tingkat pertumbuhan investasi di luar provinsi Bali. Meningkatnya jumlah investor di masa pandemi ini didominasi oleh investor yang berumur 18-25 tahun (kaum milenial) yang mencapai 33\% dari keseluruhan investor saham di Bali.

Persentase tingkat pertumbuhan investor di Kabupaten Buleleng masih terbilang rendah yaitu hanya sebesar 7\%. Kabupaten Buleleng dengan tingkat penduduk paling tinggi di Provinsi Bali seharusnya dapat menjadi kabupaten dengan tingkat pertumbuhan investor paling tinggi juga diantara kabupaten lain yang memiliki tingkat penduduk lebih rendah, dapat simpulkan bahwa minat berinvestasi masyarakat di Kabupaten Buleleng masih rendah.

Bursa Efek Indonesia dan perusahaan lainnya telah menjalin kerja sama dengan perguruan tinggi yang ada di Indonesia dengan membuka program Galeri Investasi Bursa Efek Indonesia (BEI), dengan tujuan dapat menumbuhkan minat berinvestasi pada mahasiswa. Universitas Pendidikan Ganesha (UNDIKSHA) adalah satu-satunya universitas yang memiliki galeri investasi di Kabupaten Buleleng, yang terletak di Fakultas Ekonomi, Universitas Pendidikan Ganesha. Galeri investasi digunakan untuk memfasilitasi mahasiswa yang ingin melakukan investasi di pasar modal. Responden pada penelitian ini yaitu mahasiswa S1 akuntansi, hal ini dikarenakan mahasiswa akuntansi telah mendapatkan matakuliah investasi dan pasar modal serta telah memperoleh ilmu untuk membuat, membaca, dan menganalisis laporan keuangan. Dengan kemampuan ini, mahasiswa akuntansi memiliki kemampuan lebih cermat dalam melakukan analisis saham secara fundamental sehingga mendapat manfaat yang sesuai dengan harapannya.

Pemahaman/pengetahuan dasar mengenai investasi merupakan hal sangat penting untuk diketahui oleh calon investor. Pemahaman investasi merupakan pemahaman yang harus dimiliki seseorang dalam berinvestasi dimulai dari pengetahuan dasar penilaian investasi, tingkat risikonya dan tingkat Pengetahuan yang cukup mengenai investasi bertujuan agar calon investor terhindar dari praktik-praktik investasi yang tidak rasional, penipuan, budaya ikut-ikutan, dan risiko kerugian saat berinvestasi di pasar modal, seperti pada instrumen investasi saham. Pengetahuan yang memadai akan cara berinvestasi yang benar dan tepat sangat diperlukan agar dapat menghindari terjadinya kerugian saat berinvestasi di pasar modal Isticharoh dkk, (2020). Penelitian yang dilakukan oleh Agestina dkk, (2020) menyatakan bahwa pemahaman investasi berpengaruh positif terhadap minat investasi. namun hal ini tidak sejalan dengan penelitian yang dilakukan penelitian yang dilakukan oleh Junaidi, (2019) menyatakan bahwa pemahaman investasi berpengaruh negative terhadap 
minat investasi serta penelitian yang dilakukan oleh Nisa, (2017) yang menyatakan bahwa pemahaman investasi tidak berpengaruh terhadap minat investasi.

Salah satu faktor yang dapat memicu minat seseorang khususnya mahasiswa untuk berinvestasi antara lain kemudahan dalam mengakses informasi mengenai investasi yaitu dengan menggunakan media sosial. Media sosial digunakan sebagai sarana dan tempat untuk saling berbagi informasi salah satunya mengenai investasi, mulai dari perkembangan dan pergerakan harga saham hingga informasi tentang perusahaan-perusahaan yang membutuhkan dana melalui penjualan saham di bursa efek. Semakin efektif penggunaan media sosial untuk mendapatkan informasi investasi maka semakin meningkat pula keinginan mahasiswa untuk mencoba melakukan investasi. Penelitian yang dilakukan oleh Isticharoh dkk, (2020) menyatakan bahwa penggunaan teknologi media sosial berpengaruh positif terhadap minat investasi namun hasil penelitian ini tidak sejalan dengan penelitian yang dilakukan oleh Junifa, (2019) yang menyatakan bahwa penggunaan media sosial tidak berpengaruh terhadap minat investasi.

Selain itu hubungan pertemanan adalah salah satu faktor yang dapat mempengaruhi minat berinvestasi pada generasi milenial. Sebagaimana yang kita ketahui bahwa seseorang cenderung akan terpengaruh terhadap lingkungan pergaulan atau kelompok yang ada di sekitar mereka. Dengan adanya interaksi yang terjadi pada lingkungan pertemanan akan memberikan berbagai dampak pada seseorang, baik dampak positif maupun dampak negatif pada orang tersebut. Teman yang baik berupa mengajak teman untuk berinvestasi, membuat perencanaan keuangan tiap bulannya agar keuangan dapat tertata dengan baik merupakan motivasi dari pihak eksternal yang dapat berpengaruh terhadap minat investasi mahasiswa (Nafisah, 2020).

Pertemanan antar individu dapat mempengaruhi sikap, pembicaraan, minat, penampilan dan perilaku seseorang. Mahasiswa sebagai individu senantiasa membutuhkan kehadiran orang lain dan beriteraksi dengan orang lain dalam hidupnya, untuk memenuhi hal tersebut setiap individu dalam berhubungan dengan orang lain harus dapat melakukan penyesuaian terhadap lingkungan dan sekitarnya Putra, (2019). Adanya Galeri Investasi Bursa Efek Indonesia di Fakultas Ekonomi Undiksha saat ini diharapkan mampu menularkan minat investasi dikalangan mahasiswa yang mungkin dimulai dari beberapa orang yang mempunyai minat investasi yang nantinya akan mempengaruhi temannya baik secara langsung maupun tidak langsung. Penelitian yang dilakukan oleh Putra, (2019) dan Pranyoto, (2015) menyatakan bahwa hubungan pertemanan berpengaruh positif terhadap minat investasi mahasiswa. Namun hasil penelitian ini tidak sejalan dengan penelitian yang dilakukan oleh Aprayuda, (2020) yang menyatakan bahwa hubungan pertemanan tidak berpengaruh terhadap minat investasi.

Sesuai dengan penjelasan tersebut di atas, maka hipotesis yang diuji dalam penelitian ini adalah sebagai berikut:

$H_{1}$ : hubungan pertemanan berpengaruh terhadap minat investasi generasi milenial di pasar modal

$\mathrm{H}_{2}$ : pemahaman investasi berpengaruh terhadap minat investasi generasi milenial di pasar modal

$\mathrm{H}_{3}$ : penggunaan teknologi media sosial berpengaruh terhadap minat investasi generasi milenial di pasar modal 
Tujuan dilakukannya penelitian ini adalah untuk menganalisis pengaruh pemahaman investasi, penggunaan teknologi media sosial dan hubungan pertemanan terhadap minat investasi generasi milenial di pasar modal

Penelitan ini di dasari oleh Theory of Planned Behavior yang menjelaskan bahwa manusia cenderung bertindak sesuai dengan persepsi pengendalian melalui perilaku tertentu, dimana intensi dipengaruhi oleh sikap terhadap perilaku, norma subjektif dan perceived behavior control. Dalam penelitian ini perilaku yang dimaksud adalah minat berinvestasi seorang mahasiswa yang di pengaruhi oleh pemahaman investasi, penggunaan teknologi media sosial, dan hubungan pertemanan. Serta finalcial behavior atau perilaku keuangan berkaitan dengan bagaimana cara seseorang untuk mengelola dan mempergunakan sumber daya keuangannya sendiri secara bijak.

\section{Metode}

Lokasi penelitian ini Adalah Fakultas Ekonomi, Universitas Pendidikan Ganesha. Penelitian ini menggunakan metode kuantitatif. Responden dalam penelitian ini yaitu mahasiswa program studi akuntansi, Fakultas Ekonomi universitas pendidikan ganesha (UNDIKSHA) angkatan 2017 dan 2018. .Data yang digunakan dalam penelitian ini berupa data primer karena data didapatkan langsung dari tanggapan responden atas pernyataan-pernyataan yang terdapat di dalam kuesioner yang disebarkan melaui google form. Metode sampling yang digunakan dalam penelitian ini adalah purposive sampling. Jumlah sampel dalam penelitian ini sejumlah 240 responden yang di dapat dari perhitungan rumus slovin. data yang telah dikumpulkan kemudian diolah dengan menggunakan beberapa uji statistik, yaitu (1) uji statistik deskriptif, (2) uji kualitas data yang terdiri dari uji validitas dan uji reliabilitas, (3) Uji asumsi klasik yang terdiri dari uji normalitas, uji multikolinearitas, dan uji heteroskedastisitas, (4) uji hipotesis yang terdiri dari uji regresi linear berganda, uji koefisien determinasi, dan uji t.

\section{Hasil dan Pembahasan}

Berdasarkan hasil uji statistik deskriptif dapat dinyatakan bahwa variabel pemahaman investasi (X1) mempunyai nilai terendah 17 , nilai tertinggi 25 , nilai mean 22,28 dan nilai standar deviasi sebesar 1,728. Hal tersebut menunjukan bahwa terjadi perbedaan nilai pemahaman investasi terhadap nilai rata-rata sebesar 1,728. Penggunaan teknologi media sosial (X2) mempunyai nilai terendah 20, nilai tertinggi 30, nilai mean 26,50 dan nilai standar deviasi sebesar 2,405. Hal tersebut menunjukan bahwa terjadi perbedaan nilai penggunaan teknologi media sosial terhadap nilai rata-rata sebesar 2,405. Hubungan pertemanan (X3) mempunyai nilai terendah 16 , nilai tertinggi 30 , nilai mean 25,26 dan nilai standar deviasi sebesar 2,974. Hal tersebut menunjukan bahwa terjadi perbedaan nilai hubungan pertemanan terhadap nilai rata-rata sebesar 2,974. Sedangkan minat investasi (Y) mempunyai nilai terendah 29, nilai tertinggi 40, nilai mean 35,84 dan nilai standar deviasi sebesar 2,377. Hal tersebut menunjukan bahwa terjadi perbedaan nilai minat investasi terhadap nilai rata-rata sebesar 2,377.

Tabel 1. Hasil Uji Statistika Deskriptip

\begin{tabular}{lcrrrr}
\hline & N & Minimum & Maximum & Mean & Std. Deviation \\
\hline Pemahaman Investasi & 240 & 17 & 25 & 22,28 & 1,728 \\
Penggunaan Teknologi & 240 & 20 & 30 & 26,50 & 2,405 \\
Media Sosial & 240 & 16 & 30 & 25,26 & 2,974 \\
Hubungan Pertemanan & & & &
\end{tabular}


Selain statistik deskriptif juga dilakukan uji validitas. Uji validitas dalam penelitian ini dilakukan dengan melakukan korelasi antara masing-masing skor butir pertanyaan terhadap total skor butir-butir pertanyaan dengan bantuan program SPSS 23 for Windows. Total skor butir-butir pernyataan menunjukkan hasil yang signifikan dengan sign. (2-tailed) yang bernilai < 0,05, maka masing-masing butir pertanyaan dikatakan valid. Suatu instrumen juga dapat dikatakan valid dengan metode $r$ product moment pearson apabila nilai $r$ hitung terhadap skor total lebih besar dari $r$ tabel sebesar dari 0.1267 dengan taraf signifikan 5\% dan jumlah responden sebanyak 240 responden (Sugiyono, 2011). Berdasarkan hasil uji validitas diperoleh bahwa korelasi antara masing-masing indikator atau pernyataan terhadap total skor menunjukkan hasil yang signifikan yaitu <0,05. Jadi dapat disimpulkan bahwa masing-masing indikator variabel adalah valid.

Uji kualitas data yang selanjutnya dilakukan adalah uji reliabilitas. Reliabilitas adalah sejauh mana hasil suatu pengukuran dapat dipercaya dan dapat memberikan hasil yang relative tidak berbeda apabila dilakukan kembali kepada subjek yang sama. Pada penelitian ini digunakan teknik perhitungan reliabilitas koefisien Alpha Cronbach. Kriteria keputusan reliabel atau tidaknya kuesioner adalah apabila memberikan nilai Alpha Cronbach > 0,60. Hasil uji reliabilitas masing-masing variabel diikthisarkan dalam tabel 2 berikut.

Tabel 2. Hasil Uji Reliabilitas Instrumen Penelitian

\begin{tabular}{|c|c|c|c|}
\hline No & Variabel Penelitian & $\begin{array}{c}\text { Cronbach } \\
\text { Alpha }\end{array}$ & Keterangan \\
\hline & Pemahaman Investasi $\left(\mathrm{X}_{1}\right)$ & 0,610 & Reliabel \\
\hline & Penggunaan Teknologi Media Sosial $\left(\mathrm{X}_{2}\right)$ & 0,612 & Reliabel \\
\hline & Hubungan Pertemanan $\left(\mathrm{X}_{3}\right)$ & 0,786 & Reliabel \\
\hline & Minat Investasi (Y) & 0,701 & Reliabel \\
\hline
\end{tabular}

Berdasarkan tabel 2 dapat dilihat bahwa semua variabel memiliki nilai Cronbach's Alpha $>0,60$. Variabel pemahaman investasi memiliki nilai Cronch's Alpha sebesar 0,610. Variabel penggunaan teknologi media sosial memiliki Cronch's Alpha sebesar 0,612. Variabel hubungan pertemanan memiliki Cronch's Alpha sebesar 0,786. Variabel minat investasi memiliki Cronch's Alpha sebesar 0,701. Sehingga dapat disimpulkan bahwa seluruh butir pernyataan dalam variabel tersebut adalah reliabel. Setelah uji kualitas data terpenuhi dilanjutkan dengan uji asumsi klasik. Uji asumsi klasik yang pertama adalah uji normalitas. Uji normalitas digunakan untuk menguji apakah dalam model regrasi variabel pengganggu atau residua berdistribusi normal atau tidak.

Tabel. 3. Hasil uji One Sampel Kolmogorov-Smirnov Test

\begin{tabular}{llr}
\hline & & Unstandardized residual \\
\hline $\mathrm{N}$ & & 240 \\
Normal Parameters ${ }^{\mathrm{a}, \mathrm{b}}$ & Mean & 0,0000000 \\
& Std. Deviation & 1,46434887 \\
Most Extreme Differences & Absolute & 0,055 \\
& Positive & 0,055 \\
& Negative & $-0,040$ \\
\hline
\end{tabular}


\begin{tabular}{lr} 
Test Statistic & 0,055 \\
Asymp. Sig. (2-tailed) & $0,073^{\mathrm{c}}$ \\
\hline
\end{tabular}

Pada tabel diatas nilai signifikansi 0,073 > $(0,05)$. Nilai tersebut menyatakan bahwa data dalam penelitian tersebut berdistribusi dengan normal.

Uji asumsi klasik yang kedua adalah uji multikolinearitas. Menurut Ghozali (2011), uji ini bertujuan menguji apakah pada model regresi ditemukan adanya korelasi antar variabel independen. Pada penelitian ini, untuk mendeteksi ada tidaknya multikoliniaritas dalam model regresi dapat dilihat dari tolerance value atau variance inflation factor (VIF). Jika nilai VIF tidak lebih dari 10 dan tolerance tidak kurang 0,1 maka model dapat dikatakan terbebas dari multikolinearitas, VIF $=1 /$ tolerance, jika VIF $=10$ maka tolerance $1 / 10=0,1$. Semakin tinggi VIF maka semakin rendah tolerance (Sunjoyo, et al.,2012).

Tabel 4. Hasil Uji Multikolinearitas

\begin{tabular}{|c|c|c|c|}
\hline Variabel penelitian & Nilai Toleransi & $\begin{array}{l}\text { Variance Inflation } \\
\text { Factor }\end{array}$ & Keterangan \\
\hline Pemahaman Investasi $\left(\mathrm{X}_{1}\right)$ & 0,949 & 1,054 & $\begin{array}{l}\text { Tidak terjadi } \\
\text { multikolinearitas }\end{array}$ \\
\hline $\begin{array}{l}\text { Penggunaan Teknologi Media } \\
\text { Sosial }\left(\mathrm{X}_{2}\right)\end{array}$ & 0,660 & 1,516 & $\begin{array}{l}\text { Tidak terjadi } \\
\text { multikolinearitas }\end{array}$ \\
\hline Hubungan Pertemanan $\left(X_{3}\right)$ & 0,638 & 1,567 & $\begin{array}{l}\text { Tidak terjadi } \\
\text { multikolinearitas }\end{array}$ \\
\hline
\end{tabular}

Berdasarkan hasil uji multikolinearitas yang ditunjukkan dalam tabel 4 hasil perhitungan Tolerance menunjukkan variabel pemahaman investasi, penggunaan teknologi media sosial dan hubungan pertemanan memiliki nilai tolerance yang lebih dari 0,10 yang berarti tidak ada korelasi antar variabel independen. Hasil perhitungan nilai Variance Inflation Factor (VIF) juga menunjukkan bahwa tidak ada satu variabel independen yang memiliki nilai VIF lebih dari 10, sehingga dapat disimpulkan bahwa tidak terjadi multikolinearitas antar variabel independen dalam model regresi.

Uji asumsi klasik yang ketiga adalah uji heteroskedastisitas. Uji heteroskedastisitas bertujuan untuk menguji apakah dalam model regresi terjadi ketidaksamaan variance dari residual satu pengamatan ke pengamatan lain. Pada penelitian ini, uji heteroskedastisitas dilakukan dengan menggunakan uji Glejser. Jika probabilitas signifikan masing-masing variabel independen $>0,05$, maka dapat disimpulkan tidak terjadi heteroskedastisitas dalam model regresi, namun sebaliknya jika probabilitas signifikan masing-masing variabel independen $<0,05$ maka terdapat heteroskedastisitas. (Ghozali, 2011).

Tabel 5. Hasil Uji Heteroskedastisitas

\begin{tabular}{|c|c|c|c|c|c|c|}
\hline & Model & & $\begin{array}{l}\text { dardized } \\
\text { icients }\end{array}$ & $\begin{array}{c}\text { Standardized } \\
\text { Coefficient }\end{array}$ & $T$ & $\mathrm{Siq}$ \\
\hline & IVIoder & B & $\begin{array}{l}\text { Standar } \\
\text { Eror }\end{array}$ & Beta & 1 & SIg \\
\hline 1 & (Konstan) & 3,400 & 1,071 & & 3,175 & 0,02 \\
\hline & $\begin{array}{l}\text { Pemahaman } \\
\text { Investasi }\end{array}$ & $-0,029$ & 0,038 & $-0,50$ & $-0,760$ & 0,448 \\
\hline
\end{tabular}




\begin{tabular}{llcccc}
\hline $\begin{array}{l}\text { Penggunaan } \\
\text { Teknologi Media }\end{array}$ & $-0,050$ & 0,031 & $-0,125$ & $-1,577$ & 0,116 \\
& & & & & \\
Sosial & & & & \\
Hubungan & $-0,013$ & 0,026 & $-0,042$ & $-0,519$ & 0,605 \\
Pertemanan & & & & \\
\hline
\end{tabular}

Tabel 5 memperlihatkan semua variabel bernilai signifikansi diatas 0,05 yaitu variabel pemahaman investasi bernilai 0,448 , variabel penggunaan teknologi media sosial bernilai 0,116 , dan variabel hubungan pertemanan bernilai 0,605 . Hal tersebut berarti bahwa dalam data penelitian tidak terdapat gejala heteroskedastisitas. Setelah uji asumsi klasik terpenuhi dilanjutkan dengan uji hipotesis.

Analisis regresi linear berganda merupakan alat yang digunakan untuk melakukan prediksi permintaan di masa yang akan datang, berdasarkan masa lalu atau untuk mengetahui pengaruh satu variabel bebas terhadap satu variabel tak bebas, yang memiliki tujuan untuk memprediksi besar variabel dependen dengan menggunakan data variabel independen yang sudah diketahui besarnya (Sugiyono, 2011). Variabel independen pada penelitian ini adalah pemahaman investasi, penggunaan teknologi media sosial dan hubungan pertemanan. Variabel dependen pada penelitian ini adalah minat investasi. Berdasarkan hasil pengolahan data analisis regresi berganda disajikan pada tabel 6 berikut.

Tabel 6. Hasil Uji Analisis Regresi Berganda

\begin{tabular}{|c|c|c|c|c|c|}
\hline \multirow[t]{2}{*}{ Model } & \multicolumn{2}{|c|}{$\begin{array}{l}\text { Unstandardized } \\
\text { Coefficient }\end{array}$} & \multirow{2}{*}{$\begin{array}{c}\text { Standardized } \\
\text { Coefficient } \\
\text { Beta }\end{array}$} & \multirow[t]{2}{*}{$\mathrm{T}$} & \multirow[t]{2}{*}{ Sig. } \\
\hline & B & Std. Eror & & & \\
\hline (Constant) & 16,932 & 1,663 & & 10,182 & 0,000 \\
\hline Pemahaman Investasi & $-0,104$ & 0,059 & $-0,073$ & $-1,774$ & 0,077 \\
\hline Penggunaan Teknologi Media & 0,628 & 0,049 & 0,635 & 12,863 & 0,000 \\
\hline Hubungan Pertemanan & 0,182 & 0,040 & 0,228 & 4,537 & 0,000 \\
\hline
\end{tabular}

Persamaan regresi variabel dependen dan independen dari tabel 6 diatas adalah $\mathrm{Y}=16,932-0,104 \mathrm{X} 1+0,628 \mathrm{X} 2+0,182 \mathrm{X} 3$

Nilai konstanta sebesar 116,932 menyatakan bahwa jika variabel independen dianggap konstan, maka rata-rata minat investasi adalah sebesar 16,932. Koefisien regresi pemahaman investasi (X1) sebesar -0,104 berarti bahwa bahwa jika variabel pemahaman investasi meningkat satu satuan maka minat investasi mahasiswa (Y) akan menurun sebesar $-0,104$ satuan. Koefisien regresi penggunaan teknologi media sosial (X2) sebesar 0,628 menunjukkan bahwa jika variabel penggunaan teknologi media sosial meningkat satu satuan maka minat investasi mahasiswa (Y) akan meningkat sebesar 0,628 satuan. Koefisien regresi hubungan pertemanan (X3) sebesar 0,182 menunjukkan bahwa jika variabel hubungan pertemanan meningkat satu satuan maka minat investasi mahasiswa (Y) akan meningkat sebesar 0,182 satuan.

Selanjutnya dilakukan uji koefisien determinasi untuk mengukur seberapa jauh kemampuan model dalam menjelaskan variasi variabel bebas. Nilai koefisien determinan adalah antara nol sampai satu. Apabila Adjusted R2 semakin mendekati 1, maka semakin besar variasi dalam independen variabel, ini berarti semakin tepat garis regresi tersebut untuk 
mewakili hasil observasi yang sebenarnya. Hasil uji koefisien determinasi pada penelitian ini disajikan dalam tabel 7 berikut.

Tabel 7. Hasil Uji Koefisisen determinasi

\begin{tabular}{rccrc}
\hline Model & $\mathrm{R}$ & $\mathrm{R}$ Square & $\begin{array}{c}\text { Adjusted } \mathrm{R} \\
\text { Square }\end{array}$ & $\begin{array}{c}\text { Std. Error of the } \\
\text { Estimate }\end{array}$ \\
\hline 1 & $0,788^{\mathrm{a}}$ & 0,621 & 0,616 & 1,47363 \\
\hline
\end{tabular}

Berdasarkan hasil perhitungan, diperoleh nilai Adjusted R Square sebesar 0,616 hal ini mengandung arti bahwa $62,1 \%$ variasi minat investasi dipengaruhi oleh variasi pemahaman investasi, penggunaan teknologi media sosial dan hubungan pertemanan sedangkan sisanya $37,9 \%$ dipengaruhi oleh fakta lain yang tidak dimasukkan atau diuji pada penelitian ini.

Setelah uji koefisien determinasi kemudian dilakukan uji statistik t. Uji t digunakan untuk menunjukkan seberapa jauh pengaruh satu variabel independen secara individual (persial) dalam menjelaskan variasi variabel dependen.

Tabel 8. Hasil uji signifikansi pengaruh parsial (Uji t)

\begin{tabular}{|c|c|c|c|c|c|}
\hline \multirow{2}{*}{ Variabel } & \multicolumn{5}{|c|}{ Prob. Sig } \\
\hline & $\mathrm{T}_{\text {hitung }}$ & $t_{\text {tabel }}$ & Sig & $\alpha=5 \%$ & Ket \\
\hline $\begin{array}{l}\text { Pemahaman } \\
\text { Investasi }\end{array}$ & $-1,774$ & 1,970067 & 0,077 & 0,05 & $\begin{array}{c}\text { Tidak } \\
\text { signifikan }\end{array}$ \\
\hline $\begin{array}{l}\text { Penggunaan } \\
\text { Teknologi } \\
\text { Media Sosial }\end{array}$ & 12,863 & 1,970067 & 0,000 & 0,05 & Signifikan \\
\hline $\begin{array}{l}\text { Hubungan } \\
\text { Pertemanan }\end{array}$ & 4,537 & 1,970067 & 0,000 & 0,05 & Signifikan \\
\hline
\end{tabular}

Pengaruh Pemahaman Investasi Terhadap Minat Investasi Generasi Milenial dipasar modal

Berdasarkan hasil uji statistik t, menunjukan bahwa variabel pemahaman investasi (X1) dengan nilai signifikan 0,077>0,05 dan mempunyai t hitung adalah $-1,774<$ nilai ttabel sebesar 1,970067. Jadi dapat disimpulkan bahwa H1 diterima yaitu Pemahaman Investasi memiliki pengaruh negatif tidak signifikan terhadap minat investasi di pasar modal. Hubungan antara pemahaman investasi terhadap minat investasi di pasar modal adalah semakin luas pemahaman investasi maka akan akan semakin rendah minat investasi generasi milenial di pasar modal, hal ini dikarenakan pemahaman investasi saja tidak cukup untuk dapat menumbuhkan minat berinvestasi sehingga diperlukan pelatihan-pelatihan mengenai investasi di pasar modal sehingga generasi milenial dapat langsung mempraktekkan dengan cara melakukan investasi di pasar modal.

Hasil penelitian ini berlawanan dengan hasil penelitian yang dilakukan oleh (Agestina, 2020) yang menyatakan bahwa semakin luas pemahaman investasi mahasiswa akan berpengaruh terhadap minat investasi di pasar modal, karena investor yang pemahaman investasinya luas bisa melihat keuntungan maupun risiko yang akan diperoleh saat melakukan investasi di pasar modal. Namun hasil penelitian ini sejalan dengan penelitian yang dilakukan oleh (Junaidi, 2019) dan (Alfia, 2020) menyatakan bahwa pemahaman investasi berpengaruh negative tidak signifikan terhadap minat investasi.

Peneliti menyatakan bahwa dalam hal ini dilihat bahwa pemahaman investasi yang diperoleh di bangku perkuliahan pada matakuliah investasi dan pasar modal tidak dipertimbangkan oleh mahasiswa untuk menumbuhkan minat berinvestasi di pasar modal. Seorang investor dengan pemahaman investasi saja tidak cukup untuk menumbuhkan minat 
investasi sehingga diperlukan adanya pelatihan investasi di pasar modal. Selain itu keberanian mengambil resiko juga sangat mempengaruhi minat untuk berinvestasi, hal ini didukung oleh penelitian yang dilakukan oleh Dewi, (2020) dan Titin, (2020). Karena semakin tinggi risiko yang berani diambil, maka akan semakin tinggi pula peluang keuntungan yang akan didapatkan dalam berinvestasi di pasar modal. Hal ini sejalan dengan penelitian yang dilakukan oleh Malik, (2017) menyatakan bahwa semakin tinggi risiko, maka akan semakin besar minat investor untuk berinvestasi di pasar modal

\section{Pengaruh penggunaan teknologi media sosial terhadap minat investasi generasi milenial di pasar modal}

Berdasarkan hasil uji statistik t, menunjukan bahwa variabel penggunaan teknologi media sosial (X2) dengan nilai signifikan $0,000<0,05$ dan mempunyai $t$ hitung adalah 12,863 < nilai ttabel sebesar 1,970067, maka dapat disimpulkan bahwa variabel X2 memiliki kontribusi terhadap nilai Y. Jadi dapat disimpulkan bahwa H2 diterima yaitu Penggunaan teknologi media sosial memiliki pengaruh positif signifikan terhadap minat investasi di pasar modal. Hubungan antara penggunaan teknologi media sosial dengan minat investasi generasi milenial di pasar modal adalah semakin tinggi atau efektif tingkat penggunaan teknologi media sosial dalam memenuhi informasi mengenai investasi maka akan semakin meningkat pula minat investasi generasi milenial di pasar modal.

Shabrina, (2020) menyatakan bahwa media sosial digunakan sebagai media untuk melakukan kegiatan edukasi serta memberikan kemudahan dalam mendapatkan serta berbagi informasi yang lebih cepat, dimana saja dan kapan saja. Kecepatan dan kemudahan dalam mendapatkan informasi ini sangat membantu orang-orang yang membutuhkan informasi tertentu salah satunya informasi tentang pasar modal dan investasi. Mulai dari perkembangan dan pergerakan harga saham hingga informasi tentang perusahaan-perusahaan yang membutuhkan dana melalui penjualan saham di bursa efek. Jika penggunaan media sosial dapat memberikan kemudahan untuk memperoleh informasi bagi calon investor maka akan menumbuhkan minta berinvestasi bagi generasi milenial di pasar modal.

Penelitian ini didukung oleh (Isticharoh, 2020) yang menyatakan bahwa penggunaan teknologi media sosial berpengaruh positif signifikan terhadap minat investasi. Penggunaan teknologi media sosial digunakan sebagai pertimbangan yang paling mempengaruhi mahasiswa untuk memutuskan melakukan investasi karena gaya hidup mahasiswa sekarang yang jauh lebih dekat dengan teknologi dalam mencari informasi yang lebih cepat, mudah dan akurat. Sehingga semakin baik mahasiswa dalam memanfaatkan media sosial dalam menggali informasi perusahaan, saham dan proses investasi maka semakin tinggi ketertarikan mahasiswa terhadap investasi di pasar modal.

\section{Pengaruh Hubungan Pertemanan Terhadap Minat Investasi Genrasi Milenial Di Pasar Modal}

Berdasarkan hasil uji statistik $\mathrm{t}$, menunjukan bahwa variabel hubungan pertemanan (X3) dengan nilai signifikan $0,000<0,05$ dan mempunyai t hitung adalah 4,537 < nilai ttabel sebesar 1,970067, maka dapat disimpulkan bahwa variabel X3 memiliki kontribusi terhadap nilai Y. Jadi dapat disimpulkan bahwa $\mathrm{H} 3$ diterima yaitu hubungan pertemanan memiliki pengaruh positif signifikan terhadap minat investasi di pasar modal. Hubungan antara hubungan pertemanan terhadap minat investasi generasi milenial di pasar modal adalah semakin banyak atau sering seseorag dengan lingkungan teman yang berinvestasi maka semakin besar minat minat untuk berinvestasi. 
Penelitian yang dilakukan oleh Pranyoto, (2015) menyatakan bahwa teman sebagai lingkungan sosial bagi seseorang yang memberikan peranan penting dalam perkembangan kepridadiannya dan teman juga dapat memberikan sebuah dunia tempat seseorang melakukan sosialisasi dalam suasana yang mereka ciptakan. Sehingga ketika calon investor memiliki hubungan pertemanan dengan orang yang telah menginvestasikan dananya di pasar modal hal ini juga memungkinkan dapat menumbuhkan minat berinvestasi di pasar modal.

Penelitian ini didukung oleh penelitian yang dilakukan oleh Putra, (2019) yang menyatakan bahwa hubungan pertemanan memiliki pengaruh positif signifikan terhadap minat investasi. Mahasiswa ketika cenderung bergaul dengan lingkungan orang yang melakukan investasi di pasar modal maka mahasiswa tersebut dapat memiliki minat untuk berinvestasi di pasar modal. Semakin banyak seseorang yang memiliki teman dengan lingkungan yang berinvestasi di pasar modal maka semakin besar minat untuk berinvestasi di pasar modal.

\section{Simpulan dan Saran}

Berdasarkan hasil penelitian maka dapat diambil kesimpulan yaitu 1) Pemahaman investasi berpengaruh negatif tidak signifikan terhadap minat investasi generasi milenial di pasar modal. Hal ini dapat dibuktikan dengan thitung negative sebesar $-1,774<$ tabel sebesar 1,970067dan nilai signifikan pemahaman investasi sebesar 0,077>0,05. Hal ini menunjukan bahwa pemahaman investasi yang luas belum dapat menumbuhkan minat investasi di pasar modal, 2) Penggunaan teknologi media sosial berpengaruh positif terhadap minat investasi generasi milenial di pasar modal. Hal ini dapat dibuktikan dengan thitung positif sebesar $12,863<$ ttabel sebesar 1,970067dan nilai signifikan pemahaman investasi sebesar $0,000<$ 0,05 . Hal ini menunjukan bahwa semakin efektif penggunaan teknologi media sosial dalam memperoleh informasi mengenai investasi maka akan semakin meningkat pula minat investasi generasi milenial di pasar modal, 3) Hubungan pertemanan berpengaruh positif terhadap minat investasi generasi milenial di pasar modal. Hal ini dapat dibuktikan dengan thitung positif sebesar 4,537 < tabel sebesar 1,970067 dan nilai signifikan pemahaman investasi sebesar 0,000 < 0,05. Hal ini menunjukan bahwa Semakin banyak seseorang yang memiliki teman dengan lingkungan yang berinvestasi di pasar modal maka semakin besar minat untuk berinvestasi di pasar modal.

Berdasarkan hasil penelitian yang telah dilakukan, maka saran yang dapat diberikan yaitu 1) Peneliti menyarankan untuk penelitian selanjutnya dapat menambah sampel yang lebih luas dan menambahkan variabel lainnya sehingga dapat mengetahui faktor lain yang dapat mempengaruhi minat investasi selain faktor yang digunakan dalam penelitian ini, seperti faktor pendapatan pada penelitian Rusda, (2020), pelatihan pasar modal pada penelitian Putra, (2019) dan persepsi resiko pada penelitian Malik, (2017), 2) Bagi bursa efek Indonesia (BEI) disarankan untuk lebih gencar lagi dalam melakukan sosialisasi mengenai investasi ke universitas yang tersebar diselurhh Indonesia, sehingga dapat meningkatkan jumlah investor muda yang akan melakukan investasi.

\section{Daftar Pustaka}

Agestina, Nurul Izzati Agestina, Moh Amin, and Siti Aminah Anwar. 2020. "Analisis Pengaruh Modal Minimal, Pemahaman Investasi Dan Teknologi Informasi Terhadap Minat Mahasiswa Berinvestasi Di Pasar Modal Di Tinjau Dari Perspektif Ekonomi Islam (Studi Pada Mahasiswa Fakultas Ekonomi Dan Bisnis Universitas Islam Malang).” E-Jra 09(02): 60-68. 
Aini, Nur, Maslichah, and Junaidi. 2019. "Pengaruh Pengetahuan Dan Pemahaman Investasi, Modal Minimum Investasi, Return, Risiko Dan Motivasi Investasi Terhadap Minat Mahasiswa Berinvestasi Di Pasar Modal (Studi Pada Mahasiswa Fakultas Ekonomi Dan Bisnis Kota Malang).” E-Jra 08(05): 38-52.

Alleyne, Philmore, and Tracey Broome. 2010."An Exploratory Study of Factors InfluencingInvestment Decisions of Potential Investors." : 1-22.

Aprayuda, Riyadi, and Fauzan Misra. 2020. "Factors Affecting Investment Intention of Young Investors in the Indonesian Capital Market.” E-Jurnal Akuntansi 30(5): 1084-98.

Bank, Semra, Evrim Erdogan Yazar, and Ugur Sivri. 2019. "Can Social Media Marketing Lead to Abnormal Portfolio Returns?" European Research on Management and Business Economics 25(2):54-62. https://doi.org/10.1016/j.iedeen.2019. 4.006.

Bayu Kencana. 2021. "Data Jumlah Penduduk BPS Dan Kemendagri Beda 1,15 Juta Jiwa, Kok Bisa?" Liputan6.com.https://www.liputan6.com/bisnis/read/4466563/data-jumlahpenduduk-bps-dan-kemendagri-beda-115-juta-jiwa-kok (January12, 2021).

Bisnis $\quad$ Bali. 2020 "Investor Saham Di TerusMeningkat."BisnisBali.com.http://bisnisbali.com/investor-saham-bali meningkat59-persen/ (January 18, 2021).

Herman. 2020. "Pengguna Internet Di Indonesia Capai 196,7 Juta." BeritaSatu.com. https://www.beritasatu.com/digital/696577/apjii-pengguna-internet-di indonesia-capai1967-juta (January 3, 2021).

Ismail, Shakerin, Radha K. Nair, Rohana Sham, and Siti Norida Wahab. 2018. "Impacts of Online Social Media on Investment Decision in Malaysia." Indian Journal of Public Health Research and Development 9(11): 1241-46.

Isticharoh, and Kardoyo. 2020. "Minat Investasi Diprediksi Dari Motivasi Diri, Pengetahuan Investasi, Dan Teknologi Media Sosial." Economic Education Analysis Journal 9(3): 904.

Malik, Ahmad Dahlan. 2017. "Analisa Faktor - Faktor Yang Mempengaruhi Minat Masyarakat Berinvestasi Di Pasar Modal Syariah Melalui Bursa Galeri Investasi Uisi." Jurnal Ekonomi dan Bisnis Islam (Journal of Islamic Economics and Business) 3(1): 61.

Mustika Rini. 2019. "Manfaat Investasi Di Pasar Modal Untuk Indonesia." Philip SekuritasIndonesia.https://www.poems.co.id/htm/Freeducation/LPNewsletter/v76/news 02_vol76_ManfaatInvestasiPasarmodal.html (January 9, 2021).

Nafisah, Anbar Nuha. 2020. "Pengaruh Literasi Keuangan, Teman Sebaya Dan Kontrol Diri Terhadap Perilaku Menabung (Studi Pada Mahasiswa S1 Manajemen Universitas Brawijaya Kota Malang).” Jurnal Ilmiah Mahasiswa FEB 8 (2): 1-15. 
Samudra, Teddy Briand, Maslichah, and Dwiyani Sudaryanti. 2020. "E-JRA Vol. 09 No. 02 Februari 2020 Fakultas Ekonomi Dan Bisnis Universitas Islam Malang." E-Jra 09(02): $47-57$.

Shabrina, Alya, and Zata Amani. 2020. "Pengaruh Social Media Marketing Terhadap Minat Investasi Di Pasar Modal Syariah.” Sekolah Tinggi Ekonomi Islam Tazkia. 